\title{
PROBABILISTIC ANALYSIS OF A SPACE TRUSS BY MEANS OF A MULTIDIMENSIONAL VARIABLE DESCRIPTION
}

\begin{abstract}
P. SORN ${ }^{1}$, J. GÓRSKI는. J. PRZEWLÓCKI ${ }^{3}$
Probabilistic analysis of a space truss is presented in the paper. Reliability of such a structure is sensitive to geometrical and material imperfections. The objective of this paper is to present a variant of the point estimate method (PEM) to determine mean values and standard deviations of limit loads of engineering structures. The main advantage presented by this method is the small number of sample calculations required to obtain estimators of investigated parameters. Thus the method is straightforward, requiring only preliminaries of probability theory. This approach is illustrated by limit state analysis of a space truss, considering geometric and material imperfections. The calculations were performed for different random models, so the influence of random parameters on the limit load of the truss can be determined. A realistic snow load was imposed.
\end{abstract}

Keywords: reliability, point estimated method, truss, imperfections, limit load analysis

\section{INTRODUCTION}

A large number of engineering structures exhibit great sensitivity to variations in material and geometric parameters. These fluctuations are usually random, so a probabilistic approach should be applied in engineering analysis and design. Stochastic Finite Element Method (SFEM) and the Monte Carlo simulation are the most popular methods used to assess reliability of structures with uncertain geometric and/or material parameters.

\footnotetext{
${ }^{1}$ Faculty of Civil and Environmental Engineering Technical University of Gdańsk, ul. Narutowicza 11/12, 80-233 Gdańsk,e-mail: sorn.przemek@gmail.com

${ }^{2}$ Faculty of Civil and Environmental Engineering Technical University of Gdańsk, ul. Narutowicza 11/12, 80-233 Gdańsk, e-mail: jgorski@pg.gda.pl

${ }^{3}$ Faculty of Architecture Technical University of Gdańsk, ul. Narutowicza 11/12, 80-233 Gdańsk, e-mail: jprzew@pg.gda.pl
} 
A number of methods, e.g. stratified sampling, Latin hypercube sampling, Russian roulette and many others were formulated to reduce the time of calculations. Procedures such as the First Order Second Moment (FOSM) or Second Order Second Moment (SOSM) are also widespread but restricted to specific structural classes only. Versions of Response Surface Methods were also developed.

The paper deals with applications of the point estimate method (PEM). This method allows for efficient estimation of the mean value, standard deviation and probabilistic moments of higher order of any random function. Rosenblueth [24] proposed a procedure based on a numerical integration. This method essentially involves the use of a Gaussian quadrature in order to determine probabilistic moments of a random function. The method is straightforward, requiring no perfection in the probability theory. The PEM applies a series of point estimates - point-by-point evaluations of the response function at selected values of the input of random variables in order to compute the moments of the response variable. The method applies appropriate weights to each point estimate of the response variables to compute moments under investigation. It can be readily applied to analyze response functions which cannot be formed explicitly, by closed-form expressions; another application of PEM is possible for the results of existing deterministic programs. A limitation of the Rosenblueth point estimate method for multiple variables is the need for calculations at $2^{n}$ points. This requirement significantly increases computational time and effort. When $n$ is greater than 5 or 6 the number of evaluations becomes too large for practical applications. Rosenblueth [24] also proposed a technique for reducing the number of calculation points to $2 n+1$ in a case of uncorrelated variables and the cases of neglecting the skewness. A number of researchers, including Harr [10], Lind [15] and Hong [11] modified the Rosenblueth procedure to optimize computational time and accuracy. Harr [10] considered the case of correlated, zero-skewness variables, whereas Hong [11] analysed the problem of uncorrelated variables of significant skewness. The case of large numbers of variables, including its advantages and shortcomings is widely discussed by Christian and Baecher [5].

The point estimate method has been adopted mostly in geotechnical reliability analysis. In fact, it has even become a staple in this field. For example, Suchomel and Mašín [26] used different probabilistic methods to analyze a strip footing on a horizontally stratified sandy deposit. They found the basic PEM method by Rosenblueth [24] the most accurate, though still overestimating the mean and standard deviation of a settlement. Sayed et al. [25] carried out reliability analysis using different probabilistic methods to study the stability aspects of reinforced soil retaining walls under static and seismic conditions and achieved comparable results. Baecher and Christian [1], 
Przewłócki [20] applied the point estimate method to assess load-bearing capacity of a footing. Fattah [7] used this method to estimate the bearing capacity of axially loaded piles. Gibson [9], Wang and Huang [28], Baecher and Christian [1] applied the point estimate method for a probabilistic analysis of slope design. López-Acosta and Auvinet [16] applied the method to analyze the one-dimensional steady-state flow through random porous media, whereas Franceschini et al. [8] used it for an uncertainty analysis of hydrologic response. Connor and Diederichs [6] presented a reliability-based design approach to evaluate the performance of a composite tunnel lining using a modified point estimate method. Park et al [17] described a probability-based structural design approach to underground, lined rock caverns for the bulk storage of pressurized gas, such as compressed air, compressed natural gas, or compressed gaseous hydrogen.

Only a few papers were found referring to its application to reliability of any other structural problems. Lee and Kwak [12] performed reliability analysis of plane truss structure based on the response surface method that applies the point estimate. Li [14] applied this method to analyze a problem of a cantilever beam design. Zhao and Ang [29] presented application of PEM on examples of one-storey one-bay elastoplastic frames and a two-storey one-bay truss structure. $\mathrm{Qu}$ et al [22] applied the PEM to evaluate the effect of column stiffness on infill of a typical steel plate shear wall. Li et al [13] used a point estimate method in the analysis of bolted joints in laminated composites. Zhe et al [30] analyzed fatigue life of rubberized asphalt concrete mixtures containing reclaimed asphalt pavement using PEM. Bakhary et al [2] estimated the random moments of structural parameters corresponding to undamaged and damaged states using the point estimation method, verified by Monte Carlo simulation. The procedure was applied to a numerical model of a steel frame and a laboratory tested two-span reinforced concrete slab. Analysis of reticulated shell with geometric imperfections can be found in Przewłócki et al [21].

In the paper, the point estimate method is applied to a three-dimensional (3D) truss (a reticulated shell). Buckling analysis of any reticulated shell structure should be carefully analyzed. The danger of structural node snapping should be recognized and taken into consideration. Stability of such a structure is sensitive to geometrical or material imperfections. These imperfections are of random character, so their origin and magnitude is usually difficult to determine. Thus a reliable analysis should be supported by a probabilistic description.

Geometric imperfections of vertical coordinates of structural nodes were taken into consideration. Single random variables were assumed in the first stage of analysis. Various probabilistic methods were applied: the Monte Carlo method, stratified sampling methods (the variants of equal intervals 
and equal probabilities) and the point estimate method. Appropriate conclusions were drawn based on the comparison of results.

The next stage of analysis introduced additional random variables describing geometric and material parameters of the truss. The number of random variables describing the truss model varied from two to four. Three versions of the point estimate method were applied: the standard method, the Rosenblueth algorithm [24] and the Hong approach [11]. The latter two methods allowed for a substantial reduction of the number of evaluation points. In all cases the mean limit loads and their standard deviations were estimated. Finally, sensitivity of the limit load for each variation of model, geometric and material parameters was assessed. The truss was loaded by a single force and a realistic snow load.

\section{THE POINT ESTIMATE METHOD}

The point estimate method is briefly presented and discussed in the paper, referring to Rosenblueth [24], Christian and Baecher [4], Baecher and Christian [5] and some generalizations made by Przewłócki [20].

\subsection{Classical ROSENBLUETH APPROACH}

In the point estimate method a continuous random variable is replaced by a discrete random variable consisting of $N$ pulses (Fig. 1), with a probability distribution

$$
p_{x}(x)=\sum_{i=1}^{N} \delta\left(x-x_{i}\right) p\left(x_{i}\right)
$$

where: $\delta\left(x-x_{i}\right)$ is Dirac delta, and $p\left(x_{i}\right)$ is the probability assigned to points $x_{i}$, for fixed values of random variables.

There can be an infinite number of distributions described by Eq. (2.1). An important issue is to find a small number of points $N$ of equal probabilistic moments of $k$-th order, to the continuous $X$ variable of a probability density function (PDF) $-f_{x}(x)$. The number of points $N$ selected for the estimation depends on the order of probabilistic moments to be analyzed. 
The most frequent is a two-point variant. It allows for quite accurate determination of mean value and variance of a random function. Comparing the first three probabilistic moments, determined in accordance with the definition of density or distribution probability, it may be stated:

$$
\begin{aligned}
& m_{x}=\int_{-\infty}^{\infty} x f_{x}(x) d x=\sum_{i=1}^{N} x_{i} p\left(x_{i}\right) \\
& \sigma_{x}^{2}=\int_{-\infty}^{\infty}\left(x-m_{x}\right)^{2} f_{x}(x) d x=\sum_{i=1}^{N}\left(x_{i}-m_{x}\right)^{2} p\left(x_{i}\right) \\
& \gamma_{1} \sigma_{x}^{3}=\int_{-\infty}^{\infty}\left(x-m_{x}\right)^{3} f_{x}(x) d x=\sum_{i=1}^{N}\left(x_{i}-m_{x}\right)^{3} p\left(x_{i}\right)
\end{aligned}
$$

where: $m_{x}$ - expected value, $\sigma_{x}-$ standard deviation, $\gamma_{1}$ - skewness coefficient of a random variable $X$.

Transforming random variables, $X$ into $Y$ by means of a function $y=g(x)$, a probability distribution $p_{y}(y)$ is investigated, and the probabilistic moments can be easily computed. These values estimate moments of a continuous variable $Y$, defined by its PDF: $f_{y}(y)$. The mean value of the $k^{\text {th }}$ - power of a discrete random variable $Y$, representing the continuous function $y=g(x)$, can be approximated as follows:

$$
E\left[Y^{k}\right] \approx \sum_{i=1}^{N} g^{k}\left(x_{i}\right) p\left(x_{i}\right)
$$

In the simplest case a continuous random variable whose values are $m_{x}, \sigma_{x}$ and $\gamma_{1}$ can be represented by two probabilities $p\left(x_{1}\right)=P_{-}$and $p\left(x_{2}\right)=P_{+}$(called weights) assigned to the points $x_{1} \equiv x_{-}$and $x_{2} \equiv x_{+}$(Fig. 1).

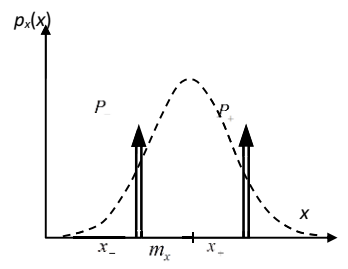

Fig.1. Probability distribution function and its representation - discrete random variables 
The certain event axiom, using symbols introduced in Eq. (2.2) leads to a following system of equations:

$$
\begin{aligned}
& P_{-}+P_{+}=1 \\
& m_{x}=x_{-} P_{-}+x_{+} P_{+} \\
& \sigma_{x}^{2}=\left(x_{-}-m_{x}\right)^{2} P_{-}+\left(x_{+}-m_{x}\right)^{2} P_{+} \\
& \gamma_{1} \sigma_{x}^{3}=\left(x_{-}-m_{x}\right)^{3} P_{-}+\left(x_{+}-m_{x}\right)^{3} P_{+}
\end{aligned}
$$

The result states the discretization points and the assigned weights:

$$
\begin{aligned}
& x_{-}=m_{x}+\left[\frac{\gamma_{1}}{2}-\sqrt{1+\left(\frac{\gamma_{1}}{2}\right)^{2}}\right] \sigma_{x}, x_{+}=m_{x}+\left[\frac{\gamma_{1}}{2}+\sqrt{1+\left(\frac{\gamma_{1}}{2}\right)^{2}}\right] \sigma_{x} \\
& P_{-}=\frac{1}{2}\left[1+\frac{\gamma_{1}}{2} \frac{1}{\sqrt{1+\left(\frac{\gamma_{1}}{2}\right)^{2}}}\right], P_{+}=1-P_{-}
\end{aligned}
$$

Simplification may be achieved for a zero skewness case, i.e. symmetric distribution. Substituting $\gamma_{1}=0$ into Eq. (2.5) it holds:

$$
x_{-}=m_{x}-\sigma_{x}, x_{+}=m_{x}+\sigma_{x}, P_{-}=\frac{1}{2}, P_{+}=\frac{1}{2}
$$

Substituting into Eq. (2.3) the following comes

$$
E\left[Y^{k}\right] \approx g^{k}\left(x_{-}\right) P_{-}+g^{k}\left(x_{+}\right) P_{+}
$$

Two probabilistic moments are derived:

$$
\begin{aligned}
m_{y} & =E\left[Y^{1}\right] \approx y_{-} P_{-}+y_{+} P_{+} \\
\sigma_{y}^{2} & =E\left[Y^{2}\right]-m_{y}^{2} \approx y_{-}^{2} P_{-}+y_{+}^{2} P_{+}-m_{y}^{2}
\end{aligned}
$$


where: $y_{+}=g\left(x_{+}\right), y_{-}=g\left(x_{-}\right)$.

While $Y$ is a function of $n$ uncorrelated random variables $X_{1}, X_{2}, \ldots, X_{n}$, of zero skewness, i.e. $y=g\left(x_{1}, x_{2}, \ldots, x_{n}\right)$, each continuous random variable may be replaced by a discrete one. Probabilities are defined for two values $x_{-}$and $x_{+}$. A number of $2^{n}$ points should be selected for estimation. A certain probability may be determined for each point, by a general formula:

$$
P_{\left(s_{1} s_{2} \ldots s_{n}\right)}=\frac{1}{2^{n}}\left[1+\sum_{i=1}^{n-1} \sum_{j=i+1}^{n}\left(s_{i}\right)\left(s_{j}\right) r_{x_{i} x_{j}}\right]
$$

where: $s_{i}= \begin{cases}-1 & \text { dla } x_{i-}=m_{x_{i}}-\sigma_{x_{i}} \\ +1 & \text { dla } x_{i+}=m_{x_{i}}+\sigma_{x_{i}}\end{cases}$

$r_{x_{i} x_{j}}-$ cross-correlation coefficient between random variables $X_{i}$ and $X_{j}$.

In a given approach the probabilistic moments of random functions are sums of all possible combinations multiplied by the products of probabilities. The Eq. (2.3) may be generalized to the case of $n$ random variables:

$$
E\left[Y^{k}\right] \approx \sum\left(y_{i}\right)^{k} P_{i}
$$

where: $y_{i}$ - value of the function designated for $x_{i}, i$-describing the position of the point $x_{i}$, $P_{i}$ - the probability assigned to the point $x_{i}$ according to Eq. (2.9).

For example, for two ( $n=2)$ random variables $X_{1}$ and $X_{2}$, the Eq. (2.9) is given

$$
P_{\left(s_{1} s_{2}\right)}=\frac{1}{4}\left[1+\left(s_{1}\right)\left(s_{2}\right) r_{x_{1} x_{2}}\right]
$$

The probabilities can be denoted with a series of + or - indicators, the first sign refers to the variable $X_{1}$, the second to $X_{2}$, the third to $X_{3}$, etc. Probabilities $P_{--}, P_{+-}, P_{-+}, P_{++}$should 
be determined at four points, with the coordinates: $\left(m_{x_{1}}-\sigma_{x_{1}}, m_{x_{2}}-\sigma_{x_{2}}\right),\left(m_{x_{1}}+\sigma_{x_{1}}, m_{x_{2}}-\sigma_{x_{2}}\right)$, $\left(m_{x_{1}}-\sigma_{x_{1}}, m_{x_{2}}+\sigma_{x_{2}}\right),\left(m_{x_{1}}+\sigma_{x_{1}}, m_{x_{2}}+\sigma_{x_{2}}\right)$, respectively. According to the Eq. (2.11) and the introduced indicators, the probabilities are equal to:

$$
P_{++}=P_{--}=\frac{1}{4}\left[1+r_{x_{1} x_{2}}\right], P_{+-}=P_{-+}=\frac{1}{4}\left[1-r_{x_{1} x_{2}}\right]
$$

In the case of $X_{1}$ and $X_{2}$ uncorrelated $\left(r_{x_{1}, x_{2}}=0\right)$, the probabilities at all points are equal to 0.25 .

The mean value and variance of a random value $Y$ according to Eq. (2.10) are given by the formulas:

$$
\begin{aligned}
m_{y} & \approx y_{++} P_{++}+y_{+-} P_{+-}+y_{-+} P_{-+}+y_{--} P_{--} \\
\sigma_{y}^{2} & \approx y_{++}^{2} P_{++}+y_{+-}^{2} P_{+-}+y_{-+}^{2} P_{-+}+y_{--}^{2} P_{--}-m_{y}^{2}
\end{aligned}
$$

where: $y_{++}=g\left(x_{1+}, x_{2+}\right), y_{+-}=g\left(x_{1+}, x_{2-}\right), y_{-+}=g\left(x_{1-}, x_{2+}\right), y_{--}=g\left(x_{1-}, x_{2-}\right)$.

In the notation above $g_{++}\left(x_{1+}, x_{2+}\right)$ means that the value is calculated for $x_{1+}=m_{x_{1}}+\sigma_{x_{1}}$, $x_{2+}=m_{x_{2}}+\sigma_{x_{2}}$, etc.

\subsection{ROSENBLUETH ALGORITHM WITH REDUCED POINTS OF EVALUATION}

The standard point estimate method is inefficient when a greater number of random variables are considered. In that case $2^{n}$ samples should be used. The Rosenblueth method [24] is one of the simplest and most effective procedures, applying only $2 n+1$ samples.

It is assumed that the following deterministic function is known (Nowak and Collins, [19]):

$$
Y=g\left(x_{1}, x_{2}, \ldots, x_{n}\right)
$$

In most cases of engineering structures this limit state function is not given explicitly. The values of this function can be obtained using any deterministic finite element program. It should be noted that the distributions of input random variables are not important - only the first two moments should be given. 
First the calculations are performed for an ideal model where all random variables are described by their mean values:

$$
y_{0}=g\left(m_{x_{1}}, m_{x_{2}}, \ldots ., m_{x_{n}}\right)
$$

Next, series of computations are performed for all random variables. Two values shifted from the mean values by $\pm \sigma_{x_{i}}$ are calculated for each random variable

$$
\begin{aligned}
& y_{i}^{+}=g\left(m_{x_{1}}, m_{x_{2}}, \ldots, m_{x_{i}}+\sigma_{x_{i}}, \ldots, m_{x_{n}}\right) \\
& y_{i}^{-}=g\left(m_{x_{1}}, m_{x_{2}}, \ldots, m_{x_{i}}-\sigma_{x_{i}}, \ldots ., m_{x_{n}}\right)
\end{aligned}
$$

On the basis the following parameters are defined:

$$
\begin{gathered}
\bar{y}_{j}=\frac{y_{i}^{+}+y_{i}^{-}}{2} \\
V_{y_{j}}=\frac{y_{i}^{+}-y_{i}^{-}}{y_{i}^{+}+y_{i}^{-}}
\end{gathered}
$$

Finally, the mean value and standard deviations are determined (Nowak and Collins, [19]):

$$
\begin{gathered}
\bar{Y}=y_{0} \prod_{i=1}^{K}\left(\frac{\bar{y}_{i}}{y_{0}}\right) \\
V_{Y}=\sqrt{\left\{\prod_{i=1}^{K}\left(1+V_{y_{i}}^{2}\right)\right\}-1}
\end{gathered}
$$

The algorithm is implemented for all presented cases. 


\subsection{HONG ALGORITHM}

The algorithm proposed by Hong [11] allows for a substantial reduction of the number of evaluation points when multivariate random calculations are performed. This method is dedicated to uncorrelated random variables only but their dispersion can be characterized by skewness. The following parameters are calculated for all random variables:

$$
\begin{aligned}
& y_{i}^{-}=g\left(m_{x_{1}}, m_{x_{2}}, \ldots ., x_{i}^{-}, \ldots ., m_{x_{n}}\right) \\
& y_{i}^{+}=g\left(m_{x_{1}}, m_{x_{2}}, \ldots ., x_{i}^{+}, \ldots ., m_{x_{n}}\right)
\end{aligned}
$$

The evaluation point and prescribed probability can be calculated using following expressions:

$$
\begin{gathered}
x_{i}=m_{x_{i}}+\sigma_{x i}\left[\frac{\gamma_{x_{i}}}{2} \pm \sqrt{n+\left(\frac{\gamma_{x_{i}}}{2}\right)^{2}}\right] \\
P_{i}=\frac{1}{2 n}\left[1 \pm \frac{\gamma_{x_{i}}}{2} \frac{1}{\sqrt{n+\left(\frac{\gamma_{x_{i}}}{2}\right)^{2}}}\right]
\end{gathered}
$$

The above algorithm allows a number of $2 n$ samples to be analyzed.

\section{SPACE TRUSS PROBABILISTIC CALCULATIONS}

A space truss (reticulated shell) was chosen to check the usefulness of the point estimate method in probabilistic analysis of engineering structures. It is well known that three-dimensional shallow trusses are extremely sensitive to variations of load and model parameters.

A three-dimensional truss structure (Fig. 2) described in Rakowski and Kacprzyk [23], was analyzed. The truss was $100 \mathrm{~m}$ long in its diameter and $8.216 \mathrm{~m}$ high. Tubular sections RO $647.8 \times 20.0$ made of S355 steel were designed for structural elements. All structural connections were made in form of ball joints. Calculations were performed using the MSC Nastran package 
[17]. Geometric and material nonlinearities were taken into account. In the first stage of calculations the simplest type of loading was assumed, i.e. a single force placed at the highest point of the structure - node no. 13 (Fig. 2). The load is not a realistic one but expected to cause an extremely sensitive mechanical response of the structure.

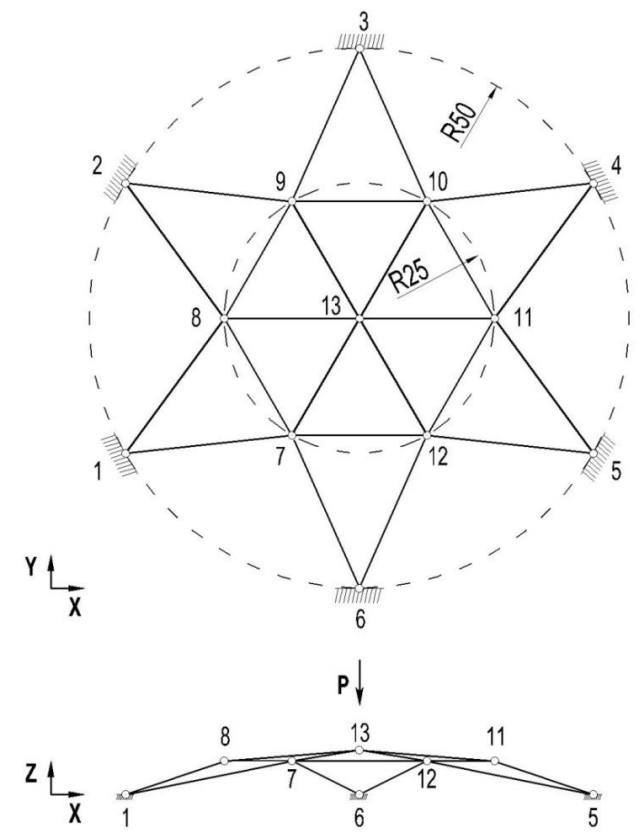

Fig. 2. Three dimensional truss structure (reticulated shell)

\subsection{ONE-DIMENSIONAL RANDOM VARIABLES}

First, the limit load for the ideal structure was calculated $R=2612.3 \mathrm{kN}$ (Fig. 3). On this basis, the limit state function was defined. Only geometric imperfections were considered. Several preliminary examples were made, proving that even small changes in the geometric description, i.e. nodal vertical coordinates, resulted in considerable changes of the limit load. For example, displacement of the highest structure point (no. 13 in Fig. 2) only $0.10 \mathrm{~m}$ down led to a $14.3 \%$ drop of the limit load (Fig. 3). It should be noted that the horizontal displacements do not significantly influence the results, thus neglected in the analysis. 


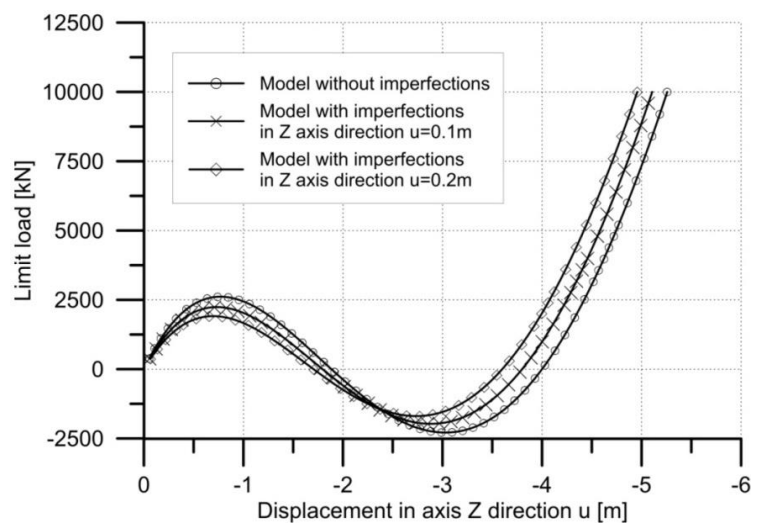

Fig.3. The equilibrium paths

In the next stage probabilistic analysis was performed. Parameters of a random geometric discrepancy were assumed as follows: mean value $m_{u}=0.0 \mathrm{~m}$ and standard deviation $\sigma_{u}=0.08 \mathrm{~m}$. Thus, the majority of the generated imperfections covered the following interval $(-0.13,0.13 \mathrm{~m})$. The assumed range of imperfections fulfills the maximum limit criteria of discrepancies allowed in fabrication of tubular elements. The initial vertical displacements of the nodes $7-12$ were computed proportionally to the discrepancies of the node no. 13 (Fig. 2). The obtained results can be considered realistic and engineeringly sound.

In order to obtain a reference limit load, the direct Monte Carlo method was applied. Calculations were performed for a population of 55 generated samples - vertical displacements of the node 13 (Fig. 2). For each generated value a response was calculated, thus distribution of the outcomes could be estimated. The accuracy of the results depends on the number of the samples used in calculations. However, nonlinear calculations for such a number of initial data are impossible due to lengthy computations. In order to determine the minimal sufficient number of field samples (estimating the results with a prescribed accuracy), convergence analysis of the outcomes was performed (Tejchman and Górski [27]). After each sample calculations, the improved expected values and standard deviations of the outcomes were estimated. Next, their variability with the growing number of samples was analysed. The calculations were finished when the scatter of the estimated values reached the assumed low level. Such analysis significantly reduced the sample numbers. It should be emphasised that during the calculation process the random field samples were not prearranged in any way; they were numerically analysed in the generation order. 
The results are presented in Figs. 4, 5 and 6. According to these computations the following values of the limit load are assumed as a reference load: mean value $m_{R}=2613.53 \mathrm{kN}$, standard deviation $\sigma_{R}=203.27 \mathrm{kN}$ and skewness $\gamma_{R}=0.0686$. Distribution of the limit load is presented in Fig. 7 . A Gaussian function was assumed to represent the dispersion of the results.

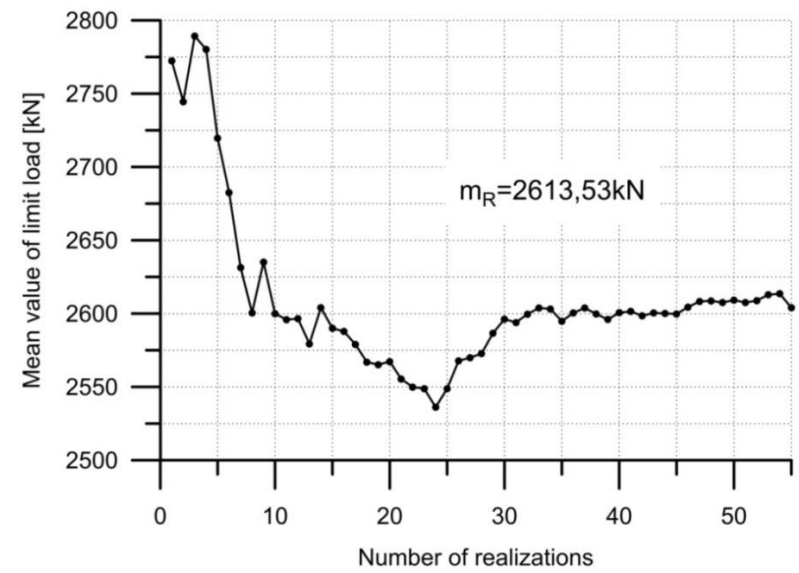

Fig.4. The direct Monte Carlo method - mean value

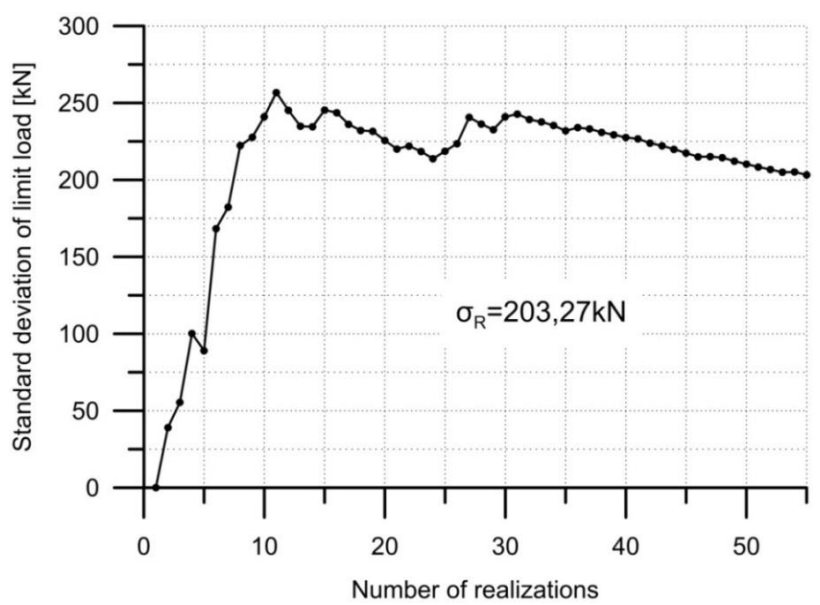

Fig.5. The direct Monte Carlo method - standard deviation 


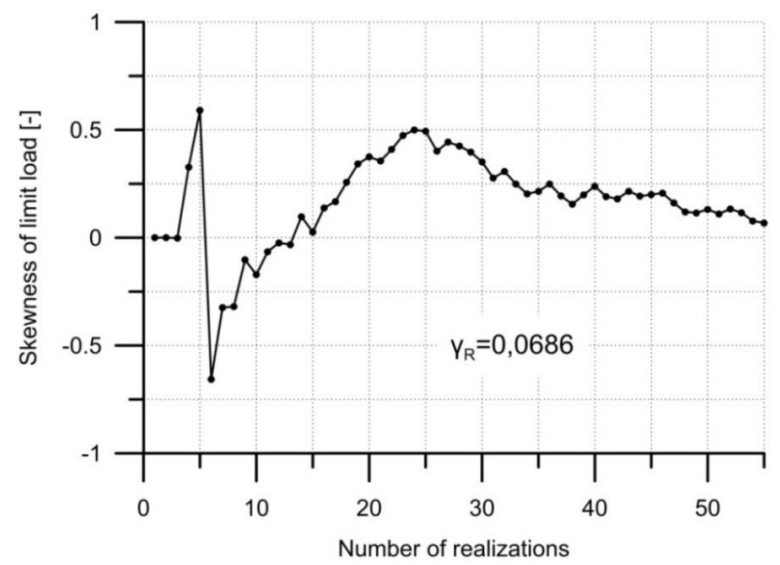

Fig. 6. The direct Monte Carlo method - skewness

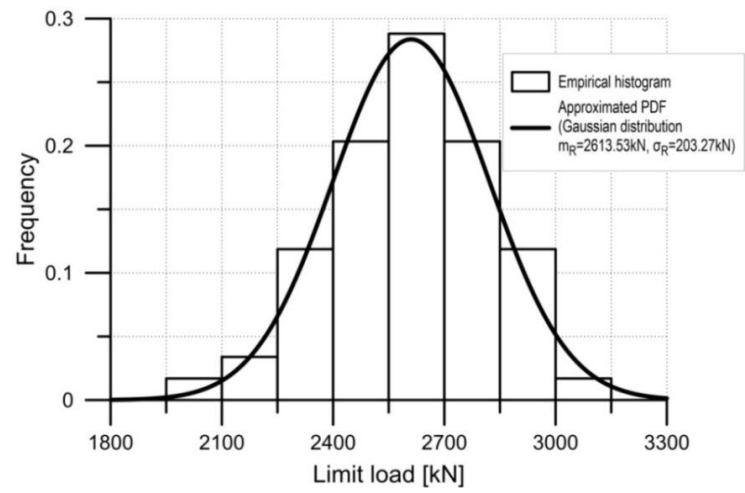

Fig. 7. The direct Monte Carlo method - PDF and histogram of limit load

Reduction of the sample space can be achieved using the Monte Carlo reduction methods. In the paper the stratified sampling method was applied (see Tejchman and Górski, [27]). The set of 55 random initial displacements were used. The number of random values was equal to the direct Monte Carlo case. The generated samples were classified and arranged with respect to the displacement magnitude. Two methods were applied, dividing the sample space into equal subsets and the subsets of equal probability. Only one sample was chosen for the analysis out of each subset. The results of calculations are presented in Figs. 8 and 9. Additionally, the results of similar calculations, using 15 and 10 samples of the direct Monte Carlo and reduced methods, are 
presented in Table 1. The comprehensive analysis proved that the stratified sampling with equal probability intervals is the most suitable method for the reliability assessment.

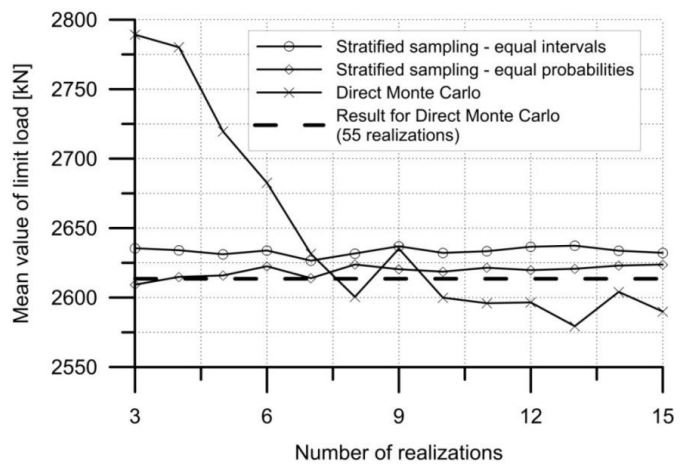

Fig. 8. Comparison of the Monte Carlo and stratified sampling - mean values

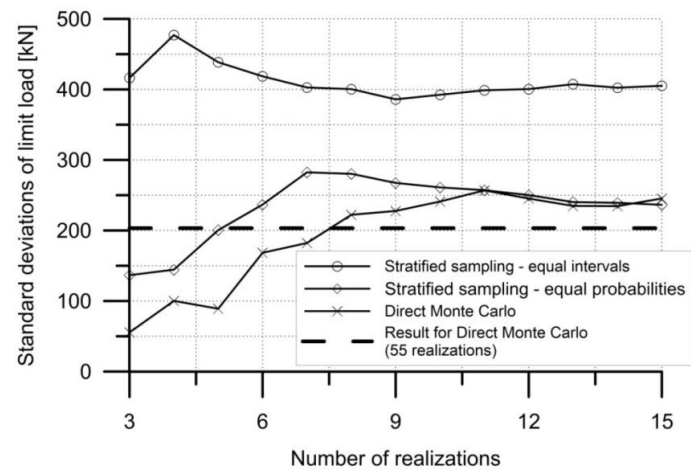

Fig. 9. Comparison of the Monte Carlo and stratified sampling - standard deviations

Table 1. Results of limit load analysis of the reticulated shell - one-dimensional case

\begin{tabular}{|c|c|c|c|}
\hline Method used & $\begin{array}{c}\text { Number } \\
\text { of realizations } n\end{array}$ & $\begin{array}{c}\text { Mean value of limit } \\
\text { load } R[\mathrm{kN}]\end{array}$ & $\begin{array}{c}\text { Standard deviation } \\
\text { of limit load } R[\mathrm{kN}]\end{array}$ \\
\hline Direct Monte Carlo & 59 & 2613.53 & 203.27 \\
\hline Direct Monte Carlo & 15 & 2604.08 & 245.38 \\
\hline Stratified sampling - equal intervals & 15 & 2632.22 & 405.12 \\
\hline Stratified sampling - equal probabilities & 15 & 2623.79 & 236.43 \\
\hline Direct Monte Carlo & 10 & 2635.18 & 241.06 \\
\hline Stratified sampling - equal intervals & 10 & 2632.18 & 392.44 \\
\hline Stratified sampling - equal probabilities & 10 & 2618.66 & 261.10 \\
\hline Point Estimate Method & 2 & 2605.12 & 239.26 \\
\hline
\end{tabular}


Next, the point estimate method was applied. In this case only two samples should be numerically analyzed. According to Eq. (2.6) two initial displacement and their weights were calculated:

$$
\begin{array}{ll}
x_{-}=0.0-0.08=-0.08 & P_{-}=0.5 \\
x_{+}=0.0+0.08=0.08 & P_{+}=0.5
\end{array}
$$

Then, the 3D truss capacities related to $x_{-}$and $x_{+}$were calculated using MSC Nastran package [18]:

$$
\begin{aligned}
& y_{-}=R\left(x_{-}\right)=2844.38 \mathrm{kN} \\
& y_{+}=R\left(x_{+}\right)=2362.86 \mathrm{kN}
\end{aligned}
$$

Substituting the above results to Eq. (2.8) estimation of mean value and standard deviation of the limit load was performed:

$$
\begin{gathered}
m_{y}=2844.38 \cdot 0.5+2365.86 \cdot 0.5=2605.12 \mathrm{kN} \\
\sigma_{R}^{2}=2844.38^{2} \cdot 0.5+2365.86^{2} \cdot 0.5-2605.12^{2}=57245.35 \mathrm{kN}^{2} \\
\sigma_{R}=\sqrt{57245.35}=239.26 \mathrm{kN}
\end{gathered}
$$

The results were compared to the Monte Carlo solution and are present in Table 1.

It should be noted that the point estimate method requires only two finite element computations to estimate mean value and standard deviation of the limit load of the truss. Relative errors, with respect to the direct Monte Carlo method are $0.2 \%$ and $12.5 \%$.

\subsection{TWO-DIMENSIONAL RANDOM VARIABLES}

The next step of the analysis concerns two random variables - geometric and material parameters. The displacements of truss nodes of two-dimensional analysis were the same as for the onedimensional case. The second parameter - Young's modulus - was assumed Gaussian, its mean value $m_{E}=210.0 \mathrm{GPa}$ and standard deviation $\sigma_{E}=4.0 \mathrm{GPa}$.

A two-dimensional image - the so called "ant hill" is presented in Fig. 10. 

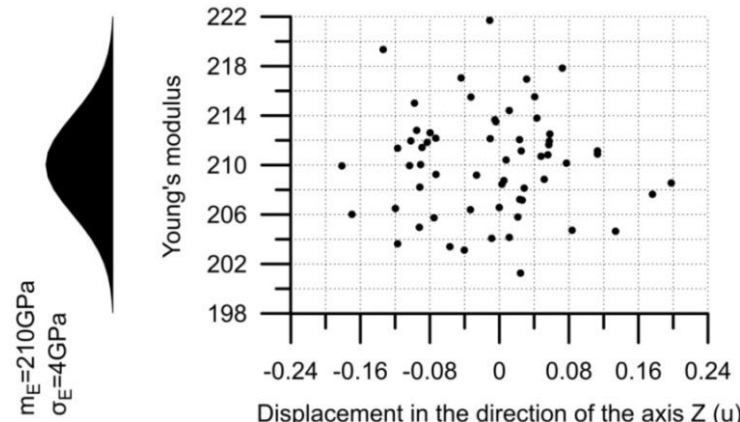

Displacement in the direction of the axis $\mathrm{Z}(\mathrm{u})$

$\mathrm{m}_{\mathrm{u}}=0,00 \mathrm{~m}$ $\sigma_{\mathrm{u}}=0,08 \mathrm{~m}$

Fig. 10. Monte Carlo method - two-dimensional variable

In the case of the Monte Carlo method 60 samples were generated, each sample is a pair of a nodal displacement and Young's modulus. The following results were obtained: mean value $m_{R}=2653.21 \mathrm{kN}$, standard deviation $\sigma_{R}=232.54 \mathrm{kN}$ and skewness $\gamma_{R}=0.1004$. Similar calculations were performed for 36, 24, 16 and 9 samples (see Table 2).

Table 2. Results of limit load analysis of a reticulated shell - two dimensional case

\begin{tabular}{|l|c|c|c|}
\hline \multicolumn{1}{|c|}{ Method used } & $\begin{array}{c}\text { Number } \\
\text { of realizations } n\end{array}$ & $\begin{array}{c}\text { Mean value } \\
\text { of resistance } R[\mathrm{kN}]\end{array}$ & $\begin{array}{c}\text { Standard deviation } \\
\text { of resistance } R[\mathrm{kN}]\end{array}$ \\
\hline Direct Monte Carlo & 60 & 2653,21 & 232,54 \\
\hline Direct Monte Carlo & 36 & 2658,71 & 229,21 \\
\hline Stratified sampling - equal intervals 6x6 & 36 & 2637,43 & 388,28 \\
\hline Stratified sampling - equal probabilities 6x6 & 36 & 2604,47 & 255,01 \\
\hline Direct Monte Carlo & 25 & 2651,48 & 227,16 \\
\hline Stratified sampling - equal intervals 5x5 & 25 & 2645,16 & 410,19 \\
\hline Stratified sampling - equal probabilities 5x5 & 25 & 2630,21 & 237,22 \\
\hline Direct Monte Carlo & 16 & 2602,15 & 253,78 \\
\hline Stratified sampling - equal intervals 4x4 & 16 & 2647,99 & 389,89 \\
\hline Stratified sampling - equal probabilities 4x4 & 16 & 2614,67 & 299,57 \\
\hline Direct Monte Carlo & 9 & 2728,93 & 309,69 \\
\hline Stratified sampling - equal intervals 3x3 & 9 & 2633,06 & 348,67 \\
\hline Stratified sampling - equal probabilities 3x3 & 9 & 2656,06 & 328,89 \\
\hline Point Estimate Method & 4 & 2620,48 & 229,38 \\
\hline
\end{tabular}


The results were compared with the outcomes of the stratified sampling method. The number of subsets was adjusted in order to obtain the number of samples equal to the direct Monte Carlo method variant i.e. $6 \times 6,5 \times 5,4 \times 4$ and $3 \times 3$.

Similarly to a single random variable case, two versions of stratified sampling were applied: using equal intervals and equal probabilities. A single truss model with geometric and material imperfections was analysed numerically.

The results (Table 2) may be considered chaotic. It is difficult to decide which of the methods is the most efficient and how many samples are required to produce satisfactory results.

In the case of the point estimate method computations were only made for four truss models (Table 3). Relative errors, with respect to the direct Monte Carlo method are $1.2 \%$ and $1.4 \%$. The results may be considered satisfactory.

Table 3. The point estimate method - two random variables

\begin{tabular}{|c|c|c|c|c|c|c|}
\hline Point & $x_{1}[\mathrm{~m}]$ & $x_{2}[\mathrm{GPa}]$ & $y[\mathrm{kN}]$ & $p\left(x_{i, j}\right)$ & $y p\left(x_{i, j}\right)$ & $y^{2} p\left(x_{i, j}\right)$ \\
\hline 1 & $x_{1-}=-0.08$ & $x_{2-}=206$ & 2790.18 & 0.25 & 697.545 & 1946276 \\
\hline 2 & $x_{1+}=0.08$ & $x_{2+}=214$ & 2443.23 & 0.25 & 610.8075 & 1492343 \\
\hline 3 & $x_{1-}=-0.08$ & $x_{2+}=214$ & 2898.30 & 0.25 & 724.575 & 2100036 \\
\hline 4 & $x_{1+}=0.08$ & $x_{2-}=206$ & 2350.19 & 0.25 & 587.548 & 1380848 \\
\hline \multicolumn{7}{|c|}{$E[R]=2620.475 \mathrm{kN}, \operatorname{Var}[R] \approx 6919503-2620.475^{2}=52614.07 \mathrm{kN}^{2}, \sigma_{R} \approx 229.38 \mathrm{kN}$} \\
\hline
\end{tabular}

\subsection{MULTIDIMENSIONAL RANDOM VARIABLES}

In the next stage a truss model with three and four random variables was considered. The combinations of variables are presented in Table 4 . The standard and Rosenblueth version of the point estimate method were applied.

Additionally, the Hong method was also applied in all cases. The results are presented in Table 5. 
Table 4. The considered cases of multivariate random variables

\begin{tabular}{|c|c|c|c|c|}
\hline Set & $\begin{array}{l}\text { Variable } \\
\text { dimension }\end{array}$ & Variable type & $\begin{array}{l}\text { Mean value } \\
\text { of random variable }\end{array}$ & $\begin{array}{l}\text { Standard deviation } \\
\text { of random variable }\end{array}$ \\
\hline \multirow[t]{2}{*}{ Set "a" } & 2 & $\begin{array}{l}\text { Initial displacement of node } 7-13 \text { calculated } \\
\text { proportionally to the displacement of node } 13\end{array}$ & $0.0 \mathrm{~m}$ & $0.08 \mathrm{~m}$ \\
\hline & & Young's modulus & $210.0 \mathrm{GPa}$ & $4.0 \mathrm{GPa}$ \\
\hline \multirow[t]{2}{*}{ Set "b" } & 2 & $\begin{array}{l}\text { Initial displacement of node } 7-13 \text { calculated } \\
\text { proportionally to the displacement of node } 13\end{array}$ & $0.0 \mathrm{~m}$ & $0.08 \mathrm{~m}$ \\
\hline & & Cross-sectional area & $394.458 \mathrm{~cm}^{2}$ & $2.000 \mathrm{~cm}^{2}$ \\
\hline \multirow[t]{2}{*}{ Set "c" } & 2 & Young's modulus & $210.0 \mathrm{GPa}$ & $4.0 \mathrm{GPa}$ \\
\hline & & Cross-sectional area & $394.458 \mathrm{~cm}^{2}$ & $2.000 \mathrm{~cm}^{2}$ \\
\hline \multirow[t]{3}{*}{ Set "d" } & 3 & $\begin{array}{l}\text { Initial displacement of node } 7-13 \text { calculated } \\
\text { proportionally to the displacement of node } 13\end{array}$ & $0.0 \mathrm{~m}$ & $0.08 \mathrm{~m}$ \\
\hline & & Young's modulus & $210.0 \mathrm{GPa}$ & $4.0 \mathrm{GPa}$ \\
\hline & & Cross-sectional area & $394.458 \mathrm{~cm}^{2}$ & $2.000 \mathrm{~cm}^{2}$ \\
\hline \multirow[t]{4}{*}{ Set “e” } & 4 & Initial displacement of node 13 & $0.0 \mathrm{~m}$ & $0.08 \mathrm{~m}$ \\
\hline & & $\begin{array}{l}\text { Initial displacement of node } 7-12 \text { calculated } \\
\text { proportionally to the displacement of node } 12\end{array}$ & $0.0 \mathrm{~m}$ & $0.03 \mathrm{~m}$ \\
\hline & & Young,s modulus & $210.0 \mathrm{GPa}$ & $4.0 \mathrm{GPa}$ \\
\hline & & Cross-sectional area & $394.458 \mathrm{~cm}^{2}$ & $2.000 \mathrm{~cm}^{2}$ \\
\hline
\end{tabular}

Table 5. Results of limit load estimation of the reticulated shell using PEM

\begin{tabular}{|c|c|c|c|c|c|c|c|c|c|}
\hline \multirow{2}{*}{ Set } & \multicolumn{2}{|c|}{$\begin{array}{c}\text { PEM - original method proposed } \\
\text { by Rosenblueth }\end{array}$} & \multicolumn{2}{|c|}{$\begin{array}{c}\text { PEM with reduction of evaluation } \\
\text { point - Rosenblueth proposition }\end{array}$} & \multicolumn{2}{|c|}{$\begin{array}{c}\text { PEM with reduction of evaluation } \\
\text { point -Hong proposition }\end{array}$} \\
\cline { 2 - 11 } & $\begin{array}{c}\text { Number } \\
\text { of } \\
\text { realizatio } \\
\mathrm{n} n\end{array}$ & $\begin{array}{c}\text { Mean } \\
\text { value of } \\
\text { limit load } \\
R[\mathrm{kN}]\end{array}$ & $\begin{array}{c}\text { Standard } \\
\text { deviation } \\
\text { of limit } \\
\text { load } \\
R[\mathrm{kN}]\end{array}$ & $\begin{array}{c}\text { Number } \\
\text { of } \\
\text { realizatio } \\
\mathrm{n} n\end{array}$ & $\begin{array}{c}\text { Mean } \\
\text { value of } \\
\text { limit load } \\
R[\mathrm{kN}]\end{array}$ & $\begin{array}{c}\text { Standard } \\
\text { deviation } \\
\text { of limit } \\
\text { load } \\
R[\mathrm{kN}]\end{array}$ & $\begin{array}{c}\text { Number } \\
\text { of } \\
\text { realizatio } \\
\mathrm{n} n\end{array}$ & $\begin{array}{c}\text { Mean } \\
\text { value of } \\
\text { limit load } \\
R[\mathrm{kN}]\end{array}$ & $\begin{array}{c}\text { Standard } \\
\text { deviation } \\
\text { of limit } \\
\text { load } \\
R[\mathrm{kN}]\end{array}$ \\
\hline "a" & 4 & 2620.49 & 229.38 & 5 & 2605,94 & 246,09 & 4 & 2620.70 & 228.94 \\
\hline "b" & 4 & 2620.24 & 223.64 & 5 & 2603,39 & 241,03 & 4 & 2620.69 & 223.85 \\
\hline "c" & 4 & 2614.52 & 51.63 & 5 & 2603,39 & 51,00 & 4 & 2613.94 & 51.78 \\
\hline "d" & 9 & 2620.58 & 265.34 & 7 & 2605,76 & 246,35 & 6 & 2606.38 & 245.94 \\
\hline “e" & 16 & 2628.49 & 363.36 & 9 & 2658,55 & 341,40 & 8 & 2628.09 & 363.64 \\
\hline
\end{tabular}

The results of various methods regarding the mean values (see Table 5) are similar. The dispersion described by standard deviations change when various sets of random variables are analyzed. Generally, a greater number of random variables produces an increment of standard deviations in the results. Values of standard deviations in set "c" suggest that the specific random variables 
defined in this set (Table 4) do not act considerably upon the results. It is easy to notice that the Hong method in four sets gives almost the same estimators of the limit load and standard deviations as in the case of the direct Monte Carlo method. The former method seems to be the most efficient in real structural analysis. Note that when a greater number of random variables is used the results diverge from the true solutions. This is because the values of random variables defined by the Hong method are not realistic. On the other hand the evaluation points calculated by the Rosenblueth method are always realistic. There is another advantage of the Rosenblueth method in comparison to the Hong method: an additional random variable $n+1$ introduced leaves the remaining $n$ results accessible. This is because the sample calculations are always performed at points defined by their mean values and standard deviations $m_{x_{n}} \pm \sigma_{x_{n}}$.

\subsection{SNOW LOAD}

The results obtained for the space truss loaded by a single force have proved that the PEM can be implemented in a real engineering analysis. A problem related to the reliability of a snow-loaded space truss was investigated.

The snow load $s\left[\mathrm{kN} / \mathrm{m}^{2}\right]$ is described by a Standard PN-EN 1991-1-3 using the formula

$$
s=\mu_{i} C_{e} C_{t} s_{k}
$$

where:

$s_{k}-$ characteristic values of ground snow load at the relevant location $\left[\mathrm{kN} / \mathrm{m}^{2}\right]$,

$\mu_{i}$ - snow load shape coefficient (roof shape factor),

$C_{e}$ - exposure coefficient (in the analysis where it is assumed that $C_{e}=1.0$ ),

$C_{t}$ - thermal coefficient (in the analysis assuming that $C_{t}=1.0$ ),

A uniformly distributed load is provided in the PN-EN 1991-1-3 code (Fig. 11). The snow load is imposed in the form of point forces at the model nodes to reflect the reactions of the roofing structure on the truss nodes.

The space truss parameters are described using four random values (Table 4, set e). The Hong version of the PEM was applied.

The following results were obtained: the mean value limit load of the space truss $m_{R}=3.85 \mathrm{kN} / \mathrm{m}^{2}$ and its standard deviation $\sigma_{R}=1.96 \mathrm{kN} / \mathrm{m}^{2}$. 


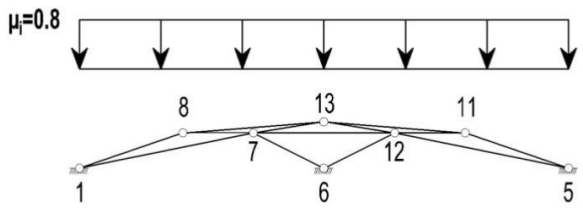

Fig. 11. Snow load

Significant difference may be observed between the results obtained for a single force loading and the realistic snow load. In the latter case nodes 7-12 are loaded, so their initial geometric displacement has a greater effect on the limit load value.

\section{ConClusions}

The point estimate method was indicated to be an efficient tool for probabilistic engineering applications. In the case of a low number of random variables (up to three) the standard analysis should be applied. In the case of greater numbers of structural random variables the point estimate method allows for a significant reduction of a sample space, not losing the accuracy of results. A greater number of random variables enable easy implementation of the Rosenblueth and Hong methods. On the other hand the field of applications for the latter methods are limited, e.g. the Hong methods may lead to unrealistic values of the evaluation points in some cases. The direct Monte Carlo method and stratified sampling method can be utilized in the case of multivariate random variables. Attention should be paid to the accuracy of results and to specific distribution types, e.g. bimodal (see Bielewicz and Górski, [3]). It should be noted that an important advantage of the point estimate method is the ability to neglect probability density functions of particular random variables in reliability analysis. Thus the method is suitable for analysing a variety of engineering problems. Investigations proved that probabilistic methods can be easily applied for standard engineering problems. The results of random analysis may substantially influence the design process.

\section{REFERENCES}

1. G. B. Baecher, J. T. Christian, Reliability and statistics in geotechnical engineering. Chichester: John Wiley \& Sons, 2003.

2. N. Bakhary, H. Hao, A. J. Deeks, "Damage detection using artificial neural network with consideration of uncertainties", Engineering Structures. 29(1), 2007, pp. 2806-2815.

3. E. Bielewicz, J. Górski, "Shell with random geometric imperfections. Simulation-based approach", International Journal of Non-linear Mechanics 37, 4-5, 2002, pp. 777-784. 
4. J. T. Christian, G. B. Baecher, "Point-estimate method as numerical quadrature", Journal of Geotechnical and Geoenvironmental Engineering. Vol. 125, No. 9, 1999, pp. 779-786.

5. J. T. Christian, G. B. Baecher, "The point-estimate method with large numbers of variables", Int. J. Numer. Anal. Meth. Geomech. 26, 2002, pp. 1515-1529.

6. L. J. Connor, M. S. Diederichs, "Reliability based approach to tunnel lining design using a modified point estimate method", International Journal of Rock Mechanics and Mining. Vol. 60, 2013, pp. 263-276.

7. M. Y. Fattah, "Reliability-based design procedure of axially loaded piles", Journal of Engineering. 16(1), 2010, pp. 4462-4477.

8. S. Franceschini, M. Marani, C. Tsai, F. Zambon, "A Perturbance Moment Point Estimate Method for uncertainty analysis of the hydrologic response", Advances in Water Resources. 40, 2012. pp. 46-53.

9. W. Gibson, "Probabilistic methods for slope analysis and design", Australian Geomechanics. 46(3), 2011, pp. $1-11$.

10. M. E. Harr, "Probabilistic estimates for multivariate analyses", Appl. Math. Modelling, 13(5), 1989, pp. 313-318.

11. H. P. Hong, "An efficient point estimate method for probabilistic analysis", Reliability Engineering and System Safety. 59(3), 1998, pp. 261-267.

12. S. H. Lee, B. M. Kwak, "Response surface augmented moment method for efficient reliability analysis", Structural Safety 28, 2006, pp. 261-272.

13. H. Li, Z. Lu, Y. Zhang, "Probabilistic strength analysis of bolted joints in laminated composites using point estimate method", Composite Structures 88, 2009, pp. 202-211.

14. H.S. Li, "Reliability-based design optimization via high order response surface method", Journal of Mechanical Science and Technology. 27 (4), 2013, pp. 1021-1029.

15. N. C. Lind, "Modelling uncertainty in discrete dynamical systems", Appl. Math. Modelling, 7(3), 1983, pp. 146-152.

16. N. P. López-Acosta, G. Auvinet, "Uncertainty in analyses of one-dimensional steady-state seepage through random porous media", Probabilistic Engineering Mechanics 26, 2011, pp. 501-510.

17. D. Park, H. M. Kim, D. W. Ryu, B. H. Choi, K. C. Han, "Probability-based structural design of lined rock caverns to resist high internal gas pressure", Engineering Geology, 153, 2013, pp. 144-151.

18. MSC Nastran for Windows. Version 2001. MSC Software Corporation. Los Angeles. USA 2001.

19. S. Nowak, K. R. Collins, Reliability of structures. McGraw-Hill Higher Education 2000.

20. J. Przewłócki, Problemy stochastycznej mechaniki gruntów - ocena niezawodności. Dolnośląskie Wydawnictwo Edukacyjne, Wrocław, 2006.

21. J. Przewłócki, J. Górski, P. Sorn, "The point estimate method in a reticulated shell reliability analysis", Lightweight Structures in Civil Engineering - IASS Contemporary Problems. Olsztyn, 2013, pp. 104-109.

22. B. Qu, X. Gou, H. Chi, M. Pollino, "Probabilistic evaluation of effect of column stiffness on seismic performance of steel plate shear walls", Engineering Structures. 43, 2012, pp. 169-179.

23. G. Rakowski, Z. Kacprzyk, Metoda elementów skończonych w mechanice konstrukcji. Oficyna Wydawnicza Politechniki Warszawskiej, Warszawa 1993.

24. E. Rosenblueth, "Point estimates for probability moments", Proc. Nat. Acad. of Sci. 72 (10), 1975, pp. 3812-3814.

25. S. Sayed, G. R. Dodagoudar, K. Rajagopal, "Reliability analysis of reinforced soil walls under static and seismic forces", Geosynthetics International, 15(4), 2008, pp. 246 - 257.

26. R. Suchomel, D. Mašín, "Probabilistic analyses of a strip footing on horizontally stratified sandy deposit using advanced constitutive model", Computers and Geotechnics. 38(3), 2011, pp. 363-374.

27. J. Tejchman, J. Górski, "Deterministic and statistical size effect during shearing of granular layer within a micro-polar hypoplasticity", International Journal for Numerical and Analytical Methods in Geomechanics, 32, 1, 2008, pp. 81-107.

28. J.P. Wang, D. Huang, "Rosen Point: A Microsoft Excel-based program for the Rosenblueth point estimate method and an application in slope stability analysis", Computers and Geosciences. 48, 2012, pp. 239-243.

29. Y.H. Zhao, H.M. Ang, "System Reliability Assessment by Method of Moments", Journal of Structural Engineering, ASCE, 129(10), 2003, pp. 1341-1349.

30. L. Zhe, X. Feipeng, H. Shaowei, Y. Yanshuang, "Probabilistic analysis on fatigue life of rubberized asphalt concrete mixtures containing reclaimed asphalt pavement", Construction and Building Materials. 41, 2013, pp. 401-410. 


\section{LIST OF FIGURES AND TABLES:}

Fig.1. Probability distribution function and its representation - discrete random variables

Rys. 1. Funkcja gęstości prawdopodobieństwa i jej reprezentacja - zmienne losowe

Fig. 2. Three dimensional truss structure (reticulated shell)

Rys. 2. Kratownica przestrzenna

Fig.3. The equilibrium paths

Rys. 3. Ścieżki równowagi

Fig.4. The direct Monte Carlo method - mean value

Rys. 4. Bezpośrednia metoda Monte Carlo - wartości oczekiwane

Fig.5. The direct Monte Carlo method - standard deviation

Rys. 5. Bezpośrednia metoda Monte Carlo - odchylenia standardowe

Fig. 6. The direct Monte Carlo method - skewness

Rys. 6. Bezpośrednia metoda Monte Carlo - skośność

Fig. 7. The direct Monte Carlo method - PDF and histogram of limit load

Rys. 7. Bezpośrednia metoda Monte Carlo - funkcja gęstości oraz histogram obciążenia granicznego

Fig. 8. Comparison of the Monte Carlo and stratified sampling - mean values

Rys. 8. Porównanie metody Monte Carlo z metodą próbkowania warstwowego - wartości oczekiwane

Fig. 9. Comparison of the Monte Carlo and stratified sampling - standard deviations

Rys. 9. Porównanie metody Monte Carlo z metodą próbkowania warstwowego - odchylenie standardowe

Fig. 10. Monte Carlo method - two-dimensional variable

Rys. 10. Metoda Monte Carlo - dwie zmienne losowe

Fig. 11. Snow load

Rys. 11. Obciążenie śniegiem

Table 1. Results of limit load analysis of the reticulated shell - one-dimensional case

Tabela 1. Wyniki analizy obciążenia granicznego kratownicy przestrzennej - jedna zmienna losowa

Table 2. Results of limit load analysis of a reticulated shell - two dimensional case

Tabela 2. Wyniki analizy obciążenia granicznego kratownicy przestrzennej - dwie zmienne losowe

Table 3. The point estimate method - two random variables

Tabela 3. Metoda estymacji punktowej - dwie zmienne losowe

Table 4. The considered cases of multivariate random variables

Tabela 4. Analizowane przypadki wielu zmiennych losowych

Table 5. Results of limit load estimation of the reticulated shell using PEM

Tabela 5. Wyniki estymacji obciążenia granicznego kratownicy przestrzennej metoda estymacji punktowej dwie zmienne losowe 


\title{
PROBABILISTYCZNA ANALIZA PRZESTRZENNEJ KRATOWNICY OPISANEJ WIELOWYMIAROWĄ ZMIENNĄ LOSOWĄ
}

\author{
Slowa kluczowe: teoria niezawodności, metoda estymacji rozkładem dyskretnym, kratownica przestrzenna, imperfekcje \\ geometryczne i materiałowe, analiza nośności granicznej
}

\section{STRESZCZENIE:}

W pracy przedstawiono probabilistyczną analizę kratownicy przestrzennej. Obciążenia graniczne tego typu konstrukcji są wrażliwe na odchyłki geometryczne oraz zmiany parametrów materiałowych. W obliczeniach niezawodności stosowanych jest wiele metod: metoda Monte Carlo, metody redukujące liczbę realizacji (np. metoda próbkowania warstwowego i hipersześcianu łacińskiego), metoda powierzchni odpowiedzi, sieci neuronowych i inne. Metoda Monte Carlo nie narzuca żadnych ograniczeń na analizowane problemy ale jej zastosowanie wymaga czasochłonnych obliczeń. Z kolei efektywne metody redukcyjne podlegają trudnym do zdefiniowania ograniczeniom. Często stosowane są tzw. metody pierwszego i drugiego rzędu (FORM, SORM), jednakże w praktyce znajdują one zastosowanie jedynie w określonej klasie zagadnień. Efektywne rozwiązanie można też uzyskać wykorzystując metodę estymacji rozkładem dyskretnym (PEM - Point Estimate Method).

Metoda ta $\mathrm{w}$ istocie polega na zastosowaniu kwadratury Gaussa do wyznaczania momentów funkcji losowej; nie wymaga specjalnej wiedzy z probabilistyki czy teorii niezawodności. Zaletą tej metody jest najczęściej niewielka liczba realizacji potrzebna do uzyskania estymatorów poszukiwanych wielkości. W celu poprawy efektywności obliczeniowej, w przypadku występowania większej liczby zmiennych losowych, powstało kilka modyfikacji tej metody. Minimalna liczba realizacji zależy od liczby zmiennych losowych $n$. Chociaż w wersji podstawowej należy obliczyć aż $2 \mathrm{n}$ realizacji, to jednak w alternatywnych podejściach liczbę tę można zredukować do $2 \mathrm{n}$ lub $2 \mathrm{n}+1$ próbek. Metoda PEM znalazła szerokie zastosowanie w wielu dziedzinach zawłaszcza w geotechnice. Jednak niewiele prac poświęcono tej metodzie w zagadnieniach dotyczących konstrukcji inżynierskich.

W pracy wykonano obliczenia przy wykorzystaniu bezpośredniej metody Monte Carlo, metody próbkowania warstwowego w dwóch wariantach oraz estymacji rozkładem dyskretnym. Jednym z celów pracy jest sprawdzenie czy wyniki uzyskiwane na podstawie probabilistycznej analizy konstrukcji za pomocą tej ostatniej metody można uznać za wystarczająco dokładne z inżynierskiego punktu widzenia. Analizę obliczeniową przeprowadzono dla kratownicy przestrzennej o rozpiętości $100 \mathrm{~m}$ i wysokości ponad $8 \mathrm{~m}$, uwzględniając geometryczne odchyłki i zmianę parametrów materiałowych. Obliczenia wykonano za pomocą programu MSC Nastran. Rozpatrzono kilka modeli losowych tak, aby ocenić wpływ przyjętych parametrów na charakterystyki statystyczne obciążenia granicznego kratownicy. Porównano wyniki obliczeń otrzymanych różnymi wariantami metody PEM z rozwiązaniem uzyskanym przy zastosowaniu bezpośredniej metody Monte Carlo.

W pierwszym modelu kratownicy przyjęto jedną zmienną losową - przemieszczenie najwyższego węzła kratownicy opisaną rozkładem normalnym. Dobrano je w taki sposób aby odzwierciedlić możliwe odchyłki wynikające z normowych tolerancji montażowych. Pozostałe węzły przemieszczono proporcjonalnie. Obciążenie stanowiło pojedyncza siła skupiona. Wykonano obliczenia dla 55 realizacji. Wyniki, tj. wartość oczekiwaną oraz odchylenie standardowe obciążenia granicznego, porównano z uzyskanymi metodą próbkowania warstwowego przy wykorzystaniu 15 i 10 realizacji. Dobrą zgodność uzyskano za pomocą metody estymacji rozkładem dyskretnym wykorzystując jedynie dwie realizacje. 
Kolejny model wzbogacono o dodatkową zmienną losową - moduł Younga. Wygenerowano 60 realizacji. Wyniki bezpośredniej Metody Monte Carlo porównano z obliczeniami wykonanymi metoda próbkowania warstwowego oraz metodą estymacji rozkładem dyskretnym. Wykonano analizę dla różnej liczby próbek. Porównanie wyników pozwoliło na stwierdzenie, ze metodę estymacji rozkładem dyskretnym można wykorzystać w obliczeniach probabilistycznych rozpatrywanej kratownicy. W kolejnych modelach kratownicy wykorzystano większą liczbę niewiadomych: od dwóch do czterech. Imperfekcje geometryczne opisano dwiema niezależnymi zmiennymi losowymi. Jako dodatkową zmienną losową przyjęto także wymiary przekroju poprzecznego prętów kratownicy. Zbudowano pięć różnych modeli konstrukcji.

W obliczeniach wykorzystano wyłącznie metodą estymacji rozkładem dyskretnym w trzech różnych wariantach: klasyczne podejście Rosenblueth'a, metodę Rosenblueth'a z redukcją punktów estymacji oraz podejście Honga również ograniczające liczbę punktów ewaluacji. Wyniki obliczeń wykonanymi różnymi wariantami metody PEM porównano ze sobą, biorąc pod uwagę liczbę obliczonych realizacji oraz wartości estymowanych parametrów probabilistycznych. Analiza wykazuje bardzo mały rozrzut wartości oczekiwanych i odchyleń standardowych obciążenia granicznego. Wykazano, że stosowanie różnych wariantów metody PEM pozwala na redukcję realizacji.

W ostatniej części przedstawiono przykład estymacji wartości oczekiwanej i odchylenia standardowego lub parametrów statystycznych nośności granicznej konstrukcji wyrażonej jako graniczną wartość charakterystycznego obciążenia śniegiem. Przyjęto schemat obciążenia śniegiem wg PN-EN 1991-1-3. Otrzymane wyniki można wykorzystać do obliczeń niezawodności rozpatrywanej konstrukcji uzależnioną od przyjętego obciążenia.

Przeprowadzona analiza wyników pokazuje, że metoda estymacji rozkładem dyskretnym jest efektywna pod względem trafności uzyskanych wyników jak i pod względem czasu jaki jest potrzebny do ich uzyskania. W przypadku niewielkiej liczby zmiennych losowych należy stosować klasyczne podejście Rosenblueth'a, natomiast w przypadku większej liczby zmiennych losowych istnieją skuteczne warianty metody PEM, umożliwiające redukcję punktów ewaluacji, co pozwala na istotne skrócenie czasu obliczeń.

Wykonane obliczenia umożliwiają oszacowanie wrażliwości obciążenia granicznego konstrukcji na zmianę poszczególnych parametrów. 
